\title{
Financial Leverage and Financial Performance of Oil and Gas Companies in Nigeria: A Re-examination
}

\author{
Ahmadu Abubakar, $\mathbf{P h D}^{\mathrm{a}}$ \\ ${ }^{\text {a }}$ Department of Business Management, Federal University Dutsin-Ma, Katsina State \\ Email:a aabubakar@fudutsinma.edu.ng
}

Article History: Received: 10 November 2020; Revised 12 January 2021 Accepted: 27 January 2021; Published online: 5 April 2021

\begin{abstract}
This study assessed the effect of financial leverage on the financial performance, using data from the annual reports of 7 quoted oil and gas firms in Nigeria, as well as from the Nigerian Stock Exchange (NSE) daily official lists over the period 2005- 2018. Descriptive statistics were used in data presentation, while random effects panel estimator was applied in determining the effect of financial leverage variables as short-term debt ratio (STDR), long-term debt ratio (LTDR) and totaldebt equity ratio (TDER) on the financial performance, measured by the return on equity (ROE). The regression results from the random effects model (REM) indicate that STDR and LTDR have no significant effect on the financial performance, and TDER has a negative but significant effect on the financial performance denoted by ROE. The study concludes that higher financial leverage of quoted oil and gas companies in Nigeria attenuates shareholders' wealth. The investment implication of this conclusion is that oil and gas companies should look more carefully at the utility maximization value of debt vis-à-vis equity in their capital structure.
\end{abstract}

Keywords: financial leverage, financial performance, oil and gas, random effects model, return on equity

\section{Introduction}

Financial leverage is the extent to which firms employ debt in the capital structure. Increase in the use of debt in a firm's capital structure increases the risk of financial distress and probability of bankruptcy which may arise as a result of default. There are certain benefits and costs associated with using debt financing. On the benefits side, firms can take advantage of tax shields benefits of debt by employing more debt in the capital structure. Interest on debt is tax deductible and the use of debt in the capital structure of firms unlike equity does not lead to dilution of ownership. However, there are certain costs associated with debt financing vis-à-vis fixed interest payments, cost of financial distress and bankruptcy costs arising from inability of firms to meet up their debt obligations as at when due. Firms must therefore, trade-off the tax shields benefits of debts against the financial distress and bankruptcy costs of debt (Abubakar, 2016).

The theory of financial leverage and its effect on financial performance has been an issue of serious debate in corporate finance literature since the seminal work of Modigliani and Miller (1958). Modigliani and Miller (1958), based on unrealistic assumptions such as existence of perfect markets, which no taxes, absence of transaction and bankruptcy costs, asserted that financial leverage has no effect on the value of a firm. In another study, Modigliani and Miller (1963) relaxed a no-tax assumption, and developed a theory about tax benefit of debt. The new theory also generated a lot discussion in the academic world.

Furthermore, there are a lot of empirical studies explaining the effect of financial leverage on the financial performance around the globe, but, there is still paucity of empirical research with respect to oil and gas sector generally, and in Nigeria in particular. This is the gap in knowledge that this study intends to fill.

\section{Literature Review}

This section provides the conceptual clarifications, theoretical framework, review of empirical studies and the development of hypotheses regarding the financial leverage variables and financial performance. The next sub section presents the conceptual clarifications.

\subsection{Conceptual Clarifications}

The key concepts of the study are briefly discussed in this sub-section. Specifically, the concepts of financial leverage, its measures, concept of financial performance, together with the justification for the proxies used are provided. 


\subsubsection{Concept And Measures Of Financial Leverage}

Financial leverage is the mixture of debt and equity in the capital structure of firms. Lumby and Jones (2011) described financial leverage as the ratio of the total market value of a company's debt capital to total market value of its equity. As debt increases, financial leverage increases. A firm can finance its investments by debt and equity, and a firm may also use preference shares. The ratio of the fixed- charge sources of funds, such as debt and preference shares to owners' equity in the capital structure is referred as financial leverage or gearing (Pandey, 2010).

The most commonly used measures of financial leverage according to Bierman (1970), are debt ratio, debtequity ratio and interest coverage. Debt ratio and debt-equity ratio can be expressed either in terms of book values or market values. The market value to financial leverage is theoretically more appropriate because market values reflect the current attitude of investors. But it is difficult to get reliable information on market values in practice. The market values of securities fluctuate quite frequently. Bowman (1980) revealed that the cross-sectional correlation between book value and market value of debt is very large, so that misspecification due to using book value measures is probably fairly small. Myers (1977) asserted that managers focused on book value leverage ratios because debt is better supported by assets in place than it is by growth opportunities implicit in asset market prices. In support of this, Fama and French (2000) argued that most of the theoretical predictions on financial leverage apply to book value.

Similarly, Thies and Klock (1992) suggested that book ratios better reflect management's target debt ratios. The market value of equity is dependent on a number of factors which are beyond the direct control of a firm. Therefore, using market values according to Thies and Klock (1992) may not reflect the underlying alterations within the firm. In fact, corporate treasurers often explicitly claim to use book ratios to avoid distortions in their financial planning caused by the volatility of market prices. A similar rationale is often heard from rating agencies (Titman and Wessels, 1988). Chen (2004) also argued that the use of book values helps avoid the limitations of missing information such as the information relating to the proportion of company stocks issued and openly traded on the stock exchange as well as capital gains in arising from a dramatic rise in asset prices. Prominent among all the arguments in favour of book values is the fact that from a more realistic point of view, the market value of debt is not readily available. Based on the foregoing arguments, debt is measured in this study using book values.

There is no difference between the debt ratio and debt-equity ratio in operational terms. The relationship between the two measures will rank companies in the same order. However, debt ratio is more specific as its value will range between zero and one. The value of debt-equity ratio may vary from zero to any large number. The debt-equity ratio, as a measure of financial leverage, is more popular in practice (Bierman, 1970).

In addition, Titman and Wessels (1988), argued that the aggregate measure of total debt ratio could not be used alone because theory of financial leverage have different implications for different type of debt, and the predicted coefficients in the structural model may differ depending on whether debt ratios are measured in terms of book or market values. In lending support to this argument, Bevan and Danbolt (2002), maintained that given the predominance of short-term debt instruments in corporate financial structure, analysis based solely upon longterm debt provide limited insight into the mechanisms which operate in the financial and corporate sectors. Based on the foregoing arguments, this study adopted four measures of financial leverage namely: short-term debt ratio; long-term debt ratio; aggregate measure of total debt ratio; and total debt-equity ratio. Interest coverage ratio which is measured as the ratio of earnings before interest and taxes (EBIT) to interest expense had been excluded from analysis because some of the firms in this study did not employ any form of financial leverage in the capital structure in a particular year, resulting to zero value for interest expense. Interest coverage ratio cannot be computed if interest expense which is the denominator in the formula is zero.

\subsubsection{Concept Of Financial Performance}

Richard et al. (2009) asserted that firm performance has been proposed as a multidimensional construct consisting of many varied areas such as operational effectiveness, corporate reputation and organizational survival. Combs et al. (2005), Hoskisson et al. (1999) and Hult et al. (2008) documented that to evaluate financial performance, organizational researchers generally use either accounting-based measures of profitability such as return on assets (ROA), return on sales (ROS) and return on equity (ROE) or stock market-based measures such as Tobin's Q and market return.

Accounting-based measures are widely regarded as valid indicators of financial performance (Gentry and Shen, 2010). Accounting measures are generally described by researchers as reflections of past or short-term financial performance, while market measures are seen as the reflections of future or long-term financial performance (Hoskisson et al., 1994; Keats and Hitt, 1988). However, it has been observed by (Gentry and Shen, 2010) that there is no consensus about the association between past/short-term performance and future/long-term 
performance. Based on the foregoing, two accounting measures (ROE and ROA) and one market performance measure (Tobin's Q) are adopted by this study.

\subsection{Theoretical Framework}

This study adopts the Pecking Order Theory. Donaldson (1961) found the pecking order theory when he conducted an interview survey of twenty-five (25) large United States (U.S) companies, and concluded that the financing pattern of the management of such firms favours strongly the use internal source of funds over external sources, unless internal sources are not readily available. Over at least two decades, Myers (1984) and Myers and Majluf (1984), provided a theoretical justification of Donaldson's (1961) findings. They argued that information plays a significant role on debt-equity choice decision of managers and investors. The authors maintained that managers will hesitate to issue equity if they feel that it is undervalued by the market, and investors too are aware that managers will hesitate to issue new equity when it is underpriced. Thus, both managers and investors react according to information available to them. Following this argument, if managers tend to issue undervalued equity, there will be wealth substitution i.e. the wealth will be transferred to the investors against the benefits and wealth of shareholders'. In this situation, internal funds and debt will be favoured over equity. Myers (1984) referred to this as the 'Pecking Order Theory' of financing.

The theory states that firms prefer to finance new investment first internally with retained earnings, second with debt, and by issuing new equity as last resort. Hence, financial leverage is negatively associated with financial performance. Pecking Order Theory suggests that there is no well-defined optimal financial leverage, because there two kinds of equity (internal and external), one at the top of the pecking order and one at the bottom.

\subsection{Review Of Empirical Studies}

In this sub-section, empirical studies relating to the association between financial leverage and financial performance on the oil and gas sector, as well as other sectors of the economy are reviewed. The review covers studies from Nigeria and other countries around the world.

Ashraf et al. (2017) conducted a study on the impact of financial leverage on firm performance using ten (10) listed firms in the Fuel and Energy Sector. The study utilized descriptive statistics, correlation and regression analyses as the techniques of analyses. The authors measured financial leverage using debt ratio, debt equity ratio and equity ratio, while return on asset, return on equity, Net Profit Margin (NPM), earnings per share and return on capital employed (ROCE) as proxies for firm performance. Results of the regression analysis reveal that debt ratio has no significant impact on all the measures of firm performance, while debt equity ratio impacts negatively on firm performance represented by the return on asset, return on equity and return on capital employed. The regression results further reveal that debt equity impacts positively on earnings per share, and has no impact on net profit margin. However, the results between equity ratio and all measures of firm performance are not reported here because equity is not a measure of financial leverage as used by the authors. Debt alone or a mixture of debt and equity can be used for both financial leverage and capital structure, but equity alone cannot be used as an indicator of financial leverage. Additionally, the authors failed to carry out a robustness check on the best performance indicator out of the five (5) measures utilized in their study.

In another more recent study in Pakistan, Nazir (2017) determined the impact of financial leverage on the financial performance of twenty (21) quoted firms from the Textile, Automobiles, Sugar, Petroleum and Engineering Sectors of Pakistan from 2012- 2015, using Ordinary Least Squares (OLS) and correlation techniques as the methods of analyses. The results reveal that financial leverage represented by debt to asset ratio has a statistically negative effect on the financial performance measured by return on asset. Racheal et al.(2017) using secondary data obtained from the annual reports and financial statements of six (6) quoted companies from the Consumer Goods Sector of Nigeria over the period 2009- 2014, evaluated the effect of financial leverage on the financial performance applying paired sample t-test as method of estimation. The use of paired sample t-test to test the effect of financial leverage on the financial performance is strange and not in conformity with the methods used by prior studies in this area. Another major weakness of Racheal et al. (2017) was that debt equity ratio the measure of financial leverage was used as dependent variable, while the measures of financial performance (earnings per share, return on equity and return on asset) were used as independent variables. Again, this is not consistent with what is applicable in extant literatures. Financial leverage is only used as dependent variable in studies of determinants of financial leverage, and not literatures investigating the effect of financial leverage on the financial performance. However, acknowledging the methodological weaknesses of the study, the authors did not find any significant association between debt equity ratio and earnings per share, while debt equity ratio has significant and positive effect on return on equity and return on asset as measures of financial performance.

Hossain and Nguyen (2016) examined capital structure and United States (U.S) financial crisis in the Oil and Gas Industry for a ten-year period from 2004 to 2013. Data was collected using secondary source from the 
financial statements of top oil and gas companies in the U.S based on market capitalization. The population was divided into three (3) namely 30 for the pre-crisis period, 30 for the crisis period and 40 for the post-crisis period, making up a total sample size of 100. The pre-crisis period is defined as the period between 2004 and 2006 , the period between 2007- 2009 is the crisis period and 2010- 2013 is tagged as the post-crisis period. Using regression technique, the authors found that financial leverage denoted by debt-equity ratio has a significant negative effect on firm performance indicators as return on equity and return on asset for each of the 10 year, and that the intensity is more pronounced during the crisis period. In Ghana, Doku et al.(2016) investigated the determinant of capital structure of listed oil marketing companies over the period 2005-2014, using ordinary least squares (OLS) regression. The findings indicate among others that financial leverage surrogated by total debt to total assets ratio has a statistical negative effect on the financial performance surrogated by return on asset.

In Kenya, Mohamed (2016) evaluated the effect of financial leverage on the financial performance of fortyeight (48) non-financial firms listed on the Nairobi Securities Exchange during the period ranging from 2011 to 2015. Secondary data was sourced from the annual reports and financial statements of the quoted firms over the period of study. Financial leverage was measured using the ratio of total debt to total assets and financial performance was measured using return on asset. Size and liquidity were taken as control variables, and given the same treatment with the measure of financial leverage. The author utilized descriptive statistics, correlation and multiple regression analyses as the methods of data analyses. The results show that financial leverage has a significant negative effect on the return on asset, whereas size and liquidity have positive effect on the financial performance proxy by return on asset.

Alghusin (2015) investigated the impact of financial leverage, company's growth, tangibility, firm size on profitability using twenty-five (25) Jordanian Industrial companies listed on the Amman Stock Exchange (ASE) from 1995- 2005. The results reveal among others that financial leverage proxy by the ratio of total debt to total asset is negatively related to financial performance denoted by ROA. Tolulope et al. (2015) analyzed the impact of capital structure on the performance of 6 quoted firms in the Oil and Gas sector of Nigeria, using Fixed Effects Model (FEM) during a 10-year period spanning from 2003- 2012. The study found among others that financial leverage measured by total debt to total assets (TDTA) has a significant negative effect on the performance represented by return on assets (ROA). Using Oil and Gas sector in Malaysia, Foo et al. (2015) examined the effect of capital structure on the corporate performance of twelve (12) Oil and Gas Companies, using panel regression techniques over the period of 2003- 2013. Capital structure is measured by short-term debt to total assets (STDTA), long-term debt to total assets (LTDTA) and total-debt to total assets (TDTA), while corporate performance is measured using return on equity, return on asset and gross margin (GM). Results from the Random Effects Model (REM) indicate that all measures of capital structure have significant negative effect on corporate performance proxy by return on equity, while all the measures of capital structure have no significant effect on corporate performance measured by return on asset and gross margin. Abubakar (2015) study of eleven (11) Tier 1, Tier II and Tier III quoted deposit money banks in Nigeria discovered significant negative relationship between debt-equity ratio and return on equity, and no significant relationship between debt ratio and the financial performance proxy by return on equity during period of 2005-2013, using correlation technique. Yahaya and Andow (2015) examined the association between capital structure and financial performance of six listed conglomerate firms in Nigeria covering the period 2009- 2013, using correlation and regression model. The multiple regression results indicate that the measures of financial leverage such as debt equity ratio, debt to total assets ratio and long term debt to total assets have no significant effect on the financial performance indicated by return on asset.

In a panel study of one hundred and one (101) non-financial quoted firms in Nigeria, Olokoyo (2013) reported significant negative association between measures of financial leverage (short-term debt to total asset, long-term debt to total asset, and total-debt to total asset) and financial performance denoted by return on asset, using random effect model (REM) covering the period 2003- 2007. However, the author also found a significant positive link between the measures of financial leverage and market performance measure denoted by Tobin's Q. In a related study, Akhtar et al. (2012) investigated the relationship between financial leverage and financial performance using twenty (20) quoted companies from the Fuel and Energy Sector of Pakistan during the period 2000- 2005. Correlation technique was used to measure the association between two (2) financial leverage variables (debt-equity ratio and capital gearing ratio) and ten (10) financial performance measures (return on equity; return on asset; dividend cover ratio; dividend to equity ratio; net profit margin; EPS before tax; EPS after tax; sales to total asset ratio; earnings per share before tax growth and sales growth). The findings show that financial leverage has a positive link with all measures of financial performance except return on asset and dividend cover ratio during the period of study. Still in Pakistan, Sabir and Malik (2012) analyzed the effect of profitability, tangibility, size and liquidity on capital structure decisions of listed companies in the Oil and Gas Sector during the period 2005-2010. The multiple regression results reveal that financial leverage is negatively statistically associated with financial performance. David and Olorunfemi (2010), using panel data approach on 
five (5) companies in the oil and gas sector of Nigeria over the period 1999-2005, reveal that financial leverage measured by debt equity ratio has a significant positive effect on the performance represented by earnings per share (EPS) and dividend per share (DPS)

\subsection{Development Of Hypotheses}

Following the review of empirical studies, this study develops and tests the following hypotheses:

$\mathrm{H}_{0} 1$ : Short-term debt ratio (STDR) has no significant effect on the firm's financial performance (ROE).

$\mathrm{H}_{0}$ 2: Long-term debt ratio (LTDR) has no significant effect on the firm's financial performance (ROE).

$\mathrm{H}_{0}$ 3: Total-debt equity ratio (TDER) has no significant effect on the firm's financial performance (ROE).

\section{Methods}

This study examined seven (7) companies that are listed on the oil and gas Sector of the Nigerian economy as at the year 2005, with continuous listed status as at $31^{\text {st }}$ December, 2018. Eight (8) firms satisfied these requirements but one company (MRS Oil Plc) has been dropped because the company did not employ any form of financial leverage between the period of 2005-2009, and retaining the company in the analysis will certainly bias the results. The seven (7) oil and gas companies used in this study are: Conoil Plc; Eterna Plc; Forte Oil Plc; Japaul Oil and Maritime Services Plc; Mobil Oil Nigeria Plc; Oando Plc and Total Nigeria Plc.

Similarly, the study covers the period 2005- 2018. The beginning period 2005 marked exactly five years after which the Nigerian accounting system witnessed a reform. Companies were mandated to prepare their financial statements in accordance with the guidelines of the International Accounting Standards (IAS). In January 2012, Nigeria adopted the International Financial Reporting Standards (IFRS). This is important because good financial reporting makes investment and financial decisions more reliable and efficient. Moreover, the study period also witnessed remarkable reforms in the financial sector such as banks recapitalization and consolidation of 2005, and there was a notable development in the Nigerian Stock Exchange. Strict regulation was implemented; more companies joined the Exchange; increase in listed securities; and increase in market capitalization. The end year 2018 was chosen because the financial statements and annual reports of the quoted firms were only available up to 2018 as at the time of carrying out this study.

Data gathering is done using annual reports of the selected oil and gas companies and the Nigerian Stock Exchange (NSE) daily official lists for the period 2005- 2018. The reports were obtained from the websites of the selected firms, NSE library in Kano, www.demo.streamicm.com, www.nse.com, www.proshareng.com and www.resoucedata.com. To measure the financial leverage variables, information on balance sheets and notes to financial statements are utilized, while the income statements (profit and loss accounts) and balance sheets are used for computing the Return on Equity (ROE) and the Return on asset (ROA), the proxies for accounting measures of performance. The market performance measure (Tobin's Q) is calculated using the information on the balance sheet and the NSE daily official lists.

The variables of the study are measured using the procedures utilized by Abubakar (2016), Olokoyo (2013) and Pandey (2010). Table 1 presents the variables and how they are measured.

Table 1: Variables and Measurement

\begin{tabular}{|c|c|}
\hline Variable & Measurement \\
\hline $\begin{array}{l}\text { Short-term debt ratio (STDR) [independent } \\
\text { variable] }\end{array}$ & $\begin{array}{l}\text { Short-term debt divided by total capital (total debt plus } \\
\text { equity) }\end{array}$ \\
\hline $\begin{array}{l}\text { Long-term debt ratio (LTDR) [independent } \\
\text { variable] }\end{array}$ & $\begin{array}{l}\text { Long-term debt divided by total capital (total debt plus } \\
\text { equity) }\end{array}$ \\
\hline $\begin{array}{l}\text { Total-debt ratio (TDR) [independent } \\
\text { variable] }\end{array}$ & $\begin{array}{l}\text { Total debt (long-term and short-term debt) divided by } \\
\text { total capital (total debt plus equity) }\end{array}$ \\
\hline $\begin{array}{l}\text { Total debt-equity ratio } \quad \text { (TDER) } \\
\text { [independent variable] }\end{array}$ & $\begin{array}{l}\text { Total debt (long-term and short-term debt) divided by } \\
\text { equity }\end{array}$ \\
\hline $\begin{array}{l}\text { Return on equity (ROE) [dependent } \\
\text { variable] }\end{array}$ & $\begin{array}{l}\text { Earnings before interest and taxes (EBIT) divided by } \\
\text { equity }\end{array}$ \\
\hline Return on asset (ROA) [dependent variable] & $\begin{array}{l}\text { Earnings before interest and taxes (EBIT) divided by } \\
\text { total asset }\end{array}$ \\
\hline Tobin's Q (dependent variable) & $\begin{array}{l}\text { Sum of book value of total debt and market value of } \\
\text { equity, divided by total asset }\end{array}$ \\
\hline
\end{tabular}

Source: Abubakar (2016), Olokoyo (2013 and Pandey (2010)

In this study, the empirical model is specified as: 
FPERF $_{\text {it }}=\alpha_{0}+\beta_{1}$ STDR $_{\text {it }}+\beta_{2}$ LTDR $_{\text {it }}+\beta_{3}$ TDR $_{\text {it }}+\beta_{4}$ TDER $_{\text {it }}+C_{i t}+\mu_{\text {it }}$

Where: FPERF = financial performance (ROE, ROA and Tobin's Q), $\alpha_{0}=$ intercept, $\beta_{1}=$ coefficient of shortterm debt ratio, STDR $=$ short-term debt ratio, $\beta_{2}=$ coefficient of long-term debt ratio, LTDR $=$ long-term debt ratio, $\beta_{3}=$ coefficient of total-debt ratio, TDR $=$ total-debt ratio, $\beta_{4}=$ coefficient of total-debt equity ratio, TDER $=$ total-debt equity ratio, subscript $\mathrm{i}$ and $\mathrm{t}$ refer to each firm $\mathrm{i}$ in year $\mathrm{t}, \mathrm{C}=$ unit-specific error component, $\mu=$ the remaining error component. Thus, the a priori expectation according to the Pecking Order Theory is $\beta_{1}$, $\beta_{2}$, $\beta_{3,}, \beta_{4}<0$.

Descriptive statistics and panel regression are used as methods of estimation. Mean; median; maximum value; minimum value; standard deviation; coefficient of variation; skewness and kurtosis are the descriptive statistics used to present the data, while Random Effects Model (REM) is the panel regression estimator applied in assessing the effect of financial leverage on the financial performance of quoted firms in the oil and gas sector of Nigeria. The use of REM followed the results of the F-test and Hausman test for best model selection. Furthermore, a balanced panel of 98 observations including seven (7) oil and gas firms and 14-year period (20052018) are used. The regression was run using the Robust Heteroscedasticity- and Autocorrelation Consistent (HAC) standard errors which is robust in the presence of Autocorrelation and Heteroscedasticity. In addition, correlation matrix and variance inflation factor (VIF) are used in deciding whether or not multicollinearity exists among the independent variables.

\section{Results And Discussion}

Here, descriptive, correlation and regression results are presented and analyzed. Descriptive result is used in presenting the data, VIF is used in taking decision about the existence of multicollinearity in the model and regression results are used in examining the effect of the independent variables on the dependent variable.

\subsection{Descriptive Results}

In Table 2, the descriptive results of the seven (7) oil and gas firms used in this study are presented. The results indicate that short-term debt ratio (STDR) has a mean value of 0.29, implying that during the period 2005-2019, approximately 29 per cent of the capital of the firms utilized in this study was financed by short-term debt. The minimum value of STDR is -3.83 while the maximum value is 0.91 . The negative sign in the minimum value portrays that at least one firm defaulted during the period of the study. In other words, the firm held negative shareholder equity.

Table 2: Descriptive Results

\begin{tabular}{llllll}
\hline Variable & STDR & LTDR & TDR & TDER & ROE \\
\hline Mean & 0.29 & 0.15 & 0.44 & 1.19 & 0.34 \\
Median & 0.34 & 0.01 & 0.44 & 0.65 & 0.37 \\
Minimum & -3.83 & 0.00 & -3.83 & -9.95 & -4.35 \\
Maximum & 0.91 & 2.38 & 2.65 & 33.85 & 1.82 \\
Std Dev. & 0.48 & 0.37 & 0.60 & 3.94 & 0.74 \\
C.V & 1.65 & 2.50 & 1.36 & 3.37 & 2.18 \\
Skewness & -6.28 & 4.02 & -2.78 & 5.78 & -3.19 \\
Kurtosis & 51.73 & 17.71 & 26.88 & 47.18 & 17.36 \\
\hline
\end{tabular}

\section{Source: Author's Computation using GRETL}

Similarly, the mean value of long-term debt ratio (LTDR) is 0.15 , portraying that only about 15 per cent of the capital of oil and gas firms used in the study was financed by long-term debt instruments. This connotes that firms in the oil and gas sector prefer or have more access to short-term financing to long-term financing during the period of study. These results are consistent with the findings of Abubakar (2016) on listed companies in the health care sector of Nigeria. Abubakar (2016) asserted that over-reliance on short-term debt exposes the firm to the risk of refinancing, and the preference for short-term over long-term debts is not unconnected with the ease of securing overdraft and other forms of short-term debt instruments. 
Additionally, the mean value of total-debt equity ratio (TDER) stood at 1.19 . This signifies that oil and gas firms employed more debt in their capital structure that equity during the period under review. Specifically, debt is about 1.19 times higher than equity in the capital structure of firms selected for this study. The implication here is that the firms are over-relying on debt; the situation which may expose defaulted firms to the risk of financial distress and bankruptcy costs. The median value of TDER is an indication that more than 50 per cent of the firms employed more equity than debt in their capital structure, as revealed by the ratio of 0.65 . The maximum value of TDER suggests that a firm had a debt profile about 34 times higher than equity in the capital structure. Furthermore, the mean value of ROE is 0.34 , connoting that worth of equity generated about $¥ 0.34$ for equity holders during the period of study. The results provide evidence that shareholders are getting fair return for their investment in the equity of firms in the oil and gas sector of Nigeria.

The descriptive results of the measures of dispersion (standard deviation and coefficient of variation [C.V]) show heterogeneity among the variables of study. The standard deviations of the variables are respectively high than means, and the C.Vs are all greater than 1, this confirm that the variables are dispersed. The skewness and kurtosis also confirm this position. Short-term debt ratio (STDR), TDR and ROE are negatively skewed, while LTDR and TDER are positively skewed. The values of kurtosis for all the variables show that they are leptokurtic in nature. To deal with heterogeneity issues, panel data techniques are used.

\subsection{Collinearity Test}

Collinearity test is conducted to discover if the independent variables have high correlation to pose a multicollinearity problem. In this regard, the correlation matrix and VIF are employed. Table 3 shows the degree of association among the independent variables. The relationship between STDR and LTDR is -0.03 ; the correlation coefficient between STDR and TDR is 0.79; while the association between STDR and TDER is 0.27.

Table 3: Correlation Matrix

\begin{tabular}{|c|c|c|c|c|c|}
\hline STD & $\begin{array}{l}\text { LTDR } \\
\text {. }\end{array}$ & TDR & & TDE & \multirow{4}{*}{ STD } \\
\hline $\mathrm{R}$ & & \multicolumn{3}{|c|}{$\mathrm{R}$} & \\
\hline \multirow[t]{7}{*}{1} & -0.03 & $0.79 * * *$ & & $0.27 *$ & \\
\hline & & & $*$ & & \\
\hline & 1 & $0.59 * * *$ & & -0.19 & LTD \\
\hline & & & & & R \\
\hline & & 1 & & $0.10 *$ & TDR \\
\hline & & & & 1 & TDE \\
\hline & & & & & $\mathrm{R}$ \\
\hline
\end{tabular}

Similarly, the correlation between LTDR and TDR is 0.59; the association between LTDR and TDER is -0.19 , and the correlation coefficient between TDR and TDER is 0.10. From the results it can be seen that no combination of two independent variables has coefficient up to 0.80. This according Gujarati (2003) and Swain (2008) may imply absence of multicollinearity since the correlation coefficient is less than 0.80 and 0.90 respectively. However, the correlation matrix is only a rule of thumb and the results need to be validated using a more scientific method. To this end, the VIF is used, and the results presented as Table 4.

Table 4: Variance Inflation Factor

\begin{tabular}{ll}
\hline Variable & Variance Inflation Factor \\
\hline STDR & 31864 \\
LTDR & 18653 \\
TDR & 48930 \\
TDER & 1.119 \\
Average & 24862 \\
\hline
\end{tabular}

Source: Author's Computation using GRETL

From the results in Table 4, values greater than 10 may indicate a collinearity problem (Rajkumar \& Hanitha, 2015). The values for STDR, LTDR and TDR and the average VIF were all greater than 10, implying the presence of multicollinearity in the model. The result of the VIF has invalidated the correlation results on the absence of collinearity. To deal with this collinearity problem, one of the variables has to be dropped, and this case TDR is 
excluded because it has the highest VIF. This leaves the study with 3 independent variables namely STDR, LTDR and TDER. To ensure that the model is completely free from collinearity problem, the VIF for the remaining three independent variables are re-computed the results shows that STDR, LTDR and TDER have VIFs of 1.078, 1.039 and 1.118 respectively. This implies that there is no multicollinearity after the removal of TDR from the model.

\subsection{Regression Results}

Return on Equity (ROE), ROA and Tobin's Q is regressed on the STDR, LTDR and TDR using Pooled Ordinary Least Squares (POLS), Fixed Effects Model (FEM) and Random Effects Model (REM). However, the results of the F-tests for ROA and Tobin's Q are not significant, meaning that the two measures of financial performance are not reliable and cannot be used in this study. This makes ROE the most robust measure of financial performance in the present study.

Following this, when the ROE is used as dependent variable, the panel estimators (POLS, FEM and REM) are statistically significant at 1 per cent level, suggesting that the 3 panel estimators can be relied upon for analyses and making policy implications. To choose the best among POLS, FEM and REM, F-test and Hausman test are carried out. Table 5 presents the results of the F-test for selecting best model between POLS and FEM.

Table 5: Results of the F- Test for Best Model Selection

\begin{tabular}{lll}
\hline Model Comparison & P-value & Remarks \\
\hline POLS-FEM & $0.001^{* * *}$ & FEM is selected \\
\hline
\end{tabular}

Significant at $1 \%(* * *)$

\section{Source: Author's Computation using GRETL}

The null hypothesis is that the seven (7) oil and gas firms have common intercept i.e. POLS is better than FEM. The decision rule is that if the test is significant, the FEM is selected. In Table 5, the result of the F-test is significant at 1 per cent level and the FEM is selected. To choose the best between FEM and REM, the Hausman test is used. Table 6 presents the result of the Hausman test. The null hypothesis is that REM is more appropriate than FEM. If the test is statistically significant, FEM is selected.

Table 6: Results of the Hausman Test

\begin{tabular}{lll}
\hline Model Comparison & P-value & Remarks \\
\hline FEM- REM & 0.121 & REM is selected \\
\hline
\end{tabular}

\section{Source: Author's Computation}

The results of Hausman test in Table 6 is not significant, therefore, REM is preferred to FEM. This makes REM the best panel estimator for this study. Consequently, analysis, conclusions and recommendations are done on the basis of REM. The regression results of the REM are presented in Table 7.

Table 7: Random-effects (GLS)

\begin{tabular}{ll}
\hline & Dependent variable: ROE \\
\hline CONSTANT & $0.48(4.33)^{* * *}$ \\
STDR & $0.06(0.45)$ \\
LTDR & $-0.09(-0.53)$ \\
TDER & $-0.12(-7.56)^{* * *}$ \\
$\mathrm{R}^{2}$ & 0.37 \\
$\mathrm{~F}$ & $18.29(0.00)^{* * *}$ \\
D-W & 1.44 \\
Significant at $\mathbf{1 \%}(* * *)$ &
\end{tabular}

The values in parenthesis for constant and variables are t-values and the one against the f-statistics is p-value.

\section{Source: Authors' Computation using GRETL}


The regression results of the REM in Table 7 indicate that STDR has no significant effect on the financial performance proxy by the ROE. The t-ratio for STDR is not significant. This implies that a change in STDR will not have any effect on ROE. Despite the high preference for short-term debt, the ratio does not impact on financial performance surrogated by ROE. This is an indication that high interest rates on debts and the fall in the oil prices in the world market are impediments to improvement in financial performance. Similarly, LTDR has no significant effect on the financial performance of quoted oil and gas firms during the period under review. This is an additional confirmation that the proportion of debt in the capital structure is not doing any good to shareholders' value measured by ROE. These findings provide support to Modigliani and Miller irrelevance theory.

Conversely, the results of the REM regression in Table 7 also indicate that TDER has a significant negative effect on the financial performance represented by the ROE, at 1 per cent level of significance. The regression coefficient of TDER is -0.12 , which connotes that a 1 per cent increase in TDER is associated with about 0.12 per cent decrease in the ROE as an indicator of the financial performance. This finding is in support of the postulation of the Pecking Order Theory which predicts that the effect financial leverage on the financial performance should be negative. This is yet additional evidence that the presence of debt in the capital structure of oil and gas firms is hurting financial performance. The finding is in consonance with the result of Ashraf et al. (2017) and, Hossain and Nguyen (2016) who all reported that TDER is statistically negatively associated with ROE of oil and gas firms in Pakistan and United States respectively. Abubakar (2016) however, pointed out that negative sign in the coefficient of TDER is an indication that the mix of debt and equity in the capital structure is non-optimal. An optimal debt-equity ratio should be able to impact positively on the financial performance.

Furthermore, the R-squared of 0.37 , which is significant at 1 per cent level, implies that the leverage variables: STDR, LTDR and TDER are responsible for about 37 per cent of the changes in the financial performance (ROE), while higher proportion of 63 per cent of the variation in the financial performance is accounted for by other factors such as total debt ratio (TDR), interest coverage ratio, firm size, dividend policy, working capital policy among others.

\section{Conclusion And Recommendations}

This study analyzed the effect of financial leverage on the financial performance of some listed oil and gas companies in Nigeria. Return on equity (ROE) was regressed on three measures of financial leverage, using three panel estimators over the period 2005 to 2018. The regression results reveal that short-term debt ratio (STDR) and long-term debt ratio (LTDR) have no significant effect on the return on equity, and total-debt equity ratio (TDER) has a significant negative effect on the financial performance measured by the return on equity.

Based on the major findings, the following conclusions are drawn:

The high presence of debt in the capital structure of oil and gas firms in Nigeria is an impediment to the progress and improvement in the financial performance of the sector. High proportion of debt in the capital structure of the firms will result in persistent decline in the shareholders' wealth denoted by ROE. In other words, higher financial leverage in the capital structure of oil and gas firms in Nigeria deteriorates shareholders' wealth measured by the ROE. Financial leverage represented by TDER is an important determinant of financial performance. The t-value of this ratio was found to be negatively significant at 1 per cent. Therefore, decrease in TDER will result in increase in the financial performance. Although, the financial leverage variables together explained the certain proportion of the variation in the ROE, there are other factors other than financial leverage that strongly determine the financial performance of oil and gas firms in Nigeria such as total debt ratio (TDR), interest coverage ratio, firm size, dividend policy, working capital policy etc.

Following the conclusions, the study recommends the following:

First, Debt-equity ratio should be reduced. The study found that a 1 per cent reduction in TDER is associated with 0.12 per cent increase in the financial performance. This can be done through reduction in debt and increase in equity. Therefore, firms in the oil and gas industry should substitute at least 90 per cent of debt in the capital structure with equity, through bonus issue, right issue and increase in retained earnings.

Second, regulatory and participatory authorities such as Securities and Exchange Commission and NSE should reduce floatation cost, transaction cost and other costs of issuing additional equity by a reasonable percentage so as to encourage firms to issue more equity.

Third, investment in the oil and gas industry is capital intensive and long-term debt used for investment in capital projects is relatively lower than short-term debt in this study. This is partly due to poor participation and inefficiency in the Nigerian capital market and partly due to unfavourable terms/ conditions imposed by lending institutions. Although, it makes economic sense to rely on external financing over internal financing for capital 
projects, higher leverage deteriorates shareholders value. Therefore, oil and gas companies should look more carefully at the utility maximization value of debt vis-à-vis equity in their capital structure

\section{References}

Abubakar, A. (2016). Financial leverage and financial performance: Evidence from the

Health care sector of the Nigerian stock exchange from 2005- 2014. ADSU Journal of Economics and Interrelated Disciplines, 1 (2): 45 - 64.

Abubakar, A. (2015). Relationship between Financial Leverage and Financial Performance of Deposit Money Banks in Nigeria. International Journal of Economics, Commerce and Management, 3 (10): $759-778$.

Akhtar, S., Javed, B., Maryam, A., and Sadia, H. (2012). Relationship between financial leverage and financial performance: Evidence from fuel and energy sector of Pakistan. European Journal of Business and Management, 4 (11): 1- 12.

Alghusin, N. A. S. (2015). Do financial leverage, growth and size affect profitability of Jordanian investment firms listed? International Journal of Academic Research in Business and Social Sciences, 5 (4): 385 - 398.

Ashraf, M., Ahmad, M. W. and Mehmood, N. (2017). The impact of financial leverage on firm performance in fuel and energy sector, Pakistan. Journal of Energy Technologies and Policies, 7 (5): 43 - 49.

Bevan, A. A., and Danbolt, J. (2002). Capital structure and its determinants in the United Kingdom- A decomposition analysis. Applied Financial Economics, 12 (3) 159- 170.

Bierman, H., J. (1970). Financial policy. London: Macmillan Publishers Ltd.

Bowman, R. G. (1980). The importance of a market-value measurement of debt in assessing leverage. Journal of Accounting Research, 18 (1): 242- 254.

Chen, J.J. (2004). Determinants of capital structure of Chinese listed companies. Journal of Business Research, 57: 1341- 1351.

Combs, J., Crook, T., and Shook, C. (2005). The dimensionality of organizational performance and its implications for strategic management research. Chapter in research methodology in strategy and management. Eds. 2. D. J Ketchen and D. D Bergth. Pp. 259- 286.

David, F. D., and Olorunfemi, S. (2010). Capital structure and corporate performance in Nigerian petroleum industry: Panel data analysis. Journal of Mathematics and Statistics, 6 (2): 168- 173.

Doku, I., Adjei, E., Adjimah, H., and Akuma, J. (2016). Determinants of capital structure of listed oil marketing companies in Ghana. American Scientific Research Journal for Engineering, Technology, and Sciences, 18 (1): $171-181$.

Donaldson, G. (1961). Corporate debt capacity: A study of corporate debt capacity. Division of research, Harvard school of business administration, Boston.

Technology, and Sciences (ASRJETS), 18 (1) 171 - 181.

Fama, E. F., and French, K.R. (2000). Testing tradeoff and pecking order predictions about dividends and debt. Working Paper, University of Chicago and Sloan School of Management (MIT).

Foo, V., Abdul Jamal, A. A., Abdul Karim, M. R., and Baharul Ulum, Z. A. (2016).

Capital structure and corporate performance: Panel evidence from oil and gas companies in Malaysia. International Journal of Business Management and Economic Research (IJBMER), 6 (6): 371- 379.

Gentry, R. J., and Shen, W. (2010). The relationship between accounting and market measures of firm performance: How strong is it? Journal of Managerial Issues, 12 (4): 514- 530.

Gujarati, D. (2003). Basic econometrics. Boston: McGraw Hill.

Hoskisson, R., Hitt, M., Wan, W., and Yiu, D. (1999). Theory and research in strategic management: Swings of pendulum. Journal of Management, 25: 417- 456.

Hoskisson, R., Johnson, R., and Moesel, D. (1994). Corporate divestiture intensity in restructuring firms- effects of government strategy and performance. Academy of Management Journal, 37: 1207- 1251.

Hossain, A., and Nguyen, X. (2016). Capital structure and U.S financial crisis: A survey

of oil and gas industry. Proceedings of the Academy Finance. Pp. 1- 14.

Hult, G., Ketchen, D., Griffith, D., Chabowski, B., Hamman, M., Dykes, B.... Cavusgil, S. (2008). An assessment of the measurement of performance in international research. Journal of International Business, 39: 1064- 1080.

Keats, B., and Hitt, M. (1988). A causal model of linkages among environmental dimensions macro organizational characteristics and performance. Academy Management Journal,13: 570- 598.

Lumby, S., and Jones, C. (2011). Corporate finance: Theory and practice (8th ed.). United Kingdom: Centage learning.

Modigliani, F. and Miller, M. (1963). Corporate income taxes and the cost of capital: A correction. American Economic Review, 53: 443- 453.

Modigliani, F. and Miller, M. H. (1958). The cost of capital, corporation finance and the theory of investment. The American Economic Review, 48 (3): 261- 297. 
Mohamed, I. B. (2016). Effect of financial leverage on financial performance of non- financial firms listed at the Nairobi securities exchange (Unpublished master project), School of Business, University of Nairobi, Kenya.

Myers, S.C. (1977). Determinants of corporate borrowing. Journal of Financial

Economics, 5: 147- 175.

Myers, S. C. (1984). The capital structure puzzle. Journal of Finance, 39 (3): 575- 592.

Myers, S., and Majluf, N. (1984). Corporate financing and investment decisions when

firms have information that investors do not have. Journal of Financial Economics, 13 (2): 187- 221.

Nazir, U. (2017). Impact of capital structure on firm's financial performance: Textile, automobile, sugar, petroleum an engineering industry of Pakistan. European Journal of Business and Management, 9 (25): 62 66.

Olokoyo, F. O. (2013). Capital structure and corporate performance of Nigerian quoted firms: A panel data approach. African Development Review, 25 (3): 358- 369.

Pandey, I. M. (2010). Financial management (10th ed.). New Delhi, India: Vikas publishing house PVT Ltd.

Racheal, J., Chelichi, I. F. and Raymond, E. A. (2017). Leverage and financial performance: Evidence from Nigerian food production firms. European Journal of Research and Reflection in Management Sciences, 5 (4): 1 - 11.

Richard, P., Devinney, T., Yip, G. and Johnson, G. (2009). Measurement organizational performance: Towards methodological best practice. Journal of Management, 35: 718-804.

Sabir, M., and Malik, Q. A. (2012). Determinant of capital structure- a study of oil and gas sector of Pakistan. Interdisciplinary Journal of Contemporary Research in Business, 3(10): 395- 400.

Swain, A. K. P. C. (2008). A text book of research methodology. New Delhi, India:

Kalyani Publishers.

Thies, C., and Klock, M. (1992). Determinants of capital structure. Review of Financial Economics, $26: 3$ - 27.

Titman, S., and Wessels, R. (1988). The determinant of capital structure choice. Journal of Finance, 43, (1): 119.

Tolulope, O., Ikpefan, A. O., and Olokoyo, F. O. (2015). An empirical analysis of capital structure on performance of firms in the petroleum industry in Nigeria. Journal of Accounting and Auditing Research and Practice, 1- 10. doi: 10.517//2015.675930.

Yahaya, O. A., and Andow, H. A. (2015). Capital structure and firm's financial performance: Panel evidence of listed conglomerates firms in Nigeria. Kaduna Business and Management Review, 2 (1): 1- 23 